\title{
Analysis of the Effectiveness of Monetary Policy Transmission Through the Exchange Rate Channel in Maintaining Price Stability in Emerging Market Countries
}

\author{
Nuraisyah Jamar ${ }^{1 *}$, Hasdi Aimon ${ }^{2}$ \\ 1,2 Universitas Negeri Padang, Padang, Indonesia \\ *Corresponding author.Email: nuraisyahjamar@gmail.com
}

\begin{abstract}
This study aims to determine the effectiveness of monetary policy transmission through the exchange rate channel in influencing price stability. This type of research is associative research. Sources of data are secondary data and data in the form of time series 1 quarter 2010 - 4 quarter 2018. The model analysis tool used is the Vector Error Correction Model (VECM). The results of the research estimate based on these indicators show that the Brazilian State exchange rate pathway has not been effective in influencing inflation as evidenced by the weak influence of the exchange rate variable on inflation, only 5.28\%. The Philippines, the exchange rate path has been effective in influencing inflation as evidenced by the strong influence of the exchange rate variable on inflation, namely $5.38 \%$. The Indonesian state, the exchange rate pathway has been effective in influencing inflation as evidenced by the strong influence of the exchange rate variable on inflation, namely $3.25 \%$,. Based on the VECM estimation results, in Brazil and the Philippines there is a short and long term relationship, while in Indonesia there is a long term relationship. In Brazil, the short and long term relations are described in time lag 4, in Indonesia the long and short term relationships created between each variable in the monetary policy transmission channel through the exchange rate channel are described in time lag 1 and the Philippines at time lag 1 . The interest rate channel is found to be the most dominant channel of monetary policy transmission in Brazil.
\end{abstract}

Keywords: Effectiveness, Monetary Policy Transmission, Exchange Rate, Price Stability, Vector Error Correction Model (VECM) and Emerging Markets.

\section{INTRODUCTION}

Monetary policy is the main factor in regulating macroeconomics in an open economy to promote economic stability and achieve development through its impact on economic variables [1]. Monetary policy has a final target to be achieved, namely economic growth and equitable development, employment opportunities, price stability, balance of payments balance. Monetary policy is a tool used to influence economic conditions, therefore it is very important to understand the channels of transmitted monetary policy [2]

Economic growth can be seen by increasing the country's output. The increase in output itself can be influenced by how effective the transmission mechanism is used by the state in its economic growth [3] .Along with developments in the financial sector other than banking and the increasingly integrated financial globalization, there are at least six channels of monetary policy transmission mechanisms that are often put forward in monetary economic theory [4].

Before monetary policy can reach its final target, it must first pass through a linkage channel called the monetary policy transmission mechanism. The monetary policy transmission mechanism can work through various channels (channels) such as: interest rates, credit, exchange rates, asset prices, and expectations. The effectiveness of monetary policy transmission is very important to determine which channels can be used for the formulation of monetary policy strategies, as well as for knowing how strong and the length of time (lag) the transmission line used can work. It is important to determine the economic 
variables used as indicators for the determination of monetary policy targets. The monetary transmission mechanism is closely related to how the actual adjustment of monetary policy variables will have an impact on real income (output) and prices [5].

In this study, the route chosen was through the exchange rate channel because in international trade, as international trade prices are closely linked to fluctuations in an exchange rate that can affect income on international trade and the volume of trade itself [6].

The direct impact of the exchange rate can play an important role in determining the direction of the relationship between interest rates and inflation [7]. Emerging market countries such as Indonesia, Brazil and the Philippines had implemented the Inflation Targetting Framework (ITF) policy and adopted a floating exchange rate system which made the role of exchange value even more important. The ITF can be believed to help achieve and maintain price stability so that monetary policy targets can be achievedauthority has made various improvements to monetary policy, data shows that inflation inflation control has not yet been achieved according to the expected target.

Table 1. Inflation Target and Actual Inflation in Emerging Market Countries for Indonesia, Brazil and the Philippines in 2010-2018

\begin{tabular}{|c|c|c|c|c|c|c|}
\hline \multirow{2}{*}{} & \multicolumn{2}{|c|}{ Brazil } & \multicolumn{2}{c|}{ Indonesia } & \multicolumn{2}{c|}{ Philippines } \\
\cline { 2 - 7 } & $\begin{array}{c}\text { Inflation } \\
\text { Target }\end{array}$ & $\begin{array}{c}\text { Actual } \\
\text { Inflation } \\
\text { (yoy) }\end{array}$ & $\begin{array}{c}\text { Inflation } \\
\text { Target }\end{array}$ & $\begin{array}{c}\text { Actual } \\
\text { Inflation } \\
\text { Year }\end{array}$ & $\begin{array}{c}\text { Inflation } \\
\text { Target }\end{array}$ & $\begin{array}{c}\text { Actual } \\
\text { Inflation } \\
\text { (\%yoy })\end{array}$ \\
\hline 2000 & $5-7 \%$ & 7,04 & $5 \%-7 \%$ & 3,68 & - & - \\
\hline 2001 & $4 \%-6 \%$ & 6,84 & $4 \%-6 \%$ & 12,55 & - & - \\
\hline 2002 & $9 \%-10 \%$ & 8,45 & $9 \%-10 \%$ & 10,03 & $4.5-5.5 \%$ & $3.00 \%$ \\
\hline 2003 & $9 \pm 1 \%$ & 14,71 & $9 \pm 1 \%$ & 5,06 & $4.5-5.5 \%$ & $3.00 \%$ \\
\hline 2004 & $5,5 \pm 1 \%$ & 6,59 & $5,5 \pm 1 \%$ & 6,40 & $4.0-5.0 \%$ & $5.50 \%$ \\
\hline 2005 & $6 \pm 1 \%$ & 6,86 & $6 \pm 1 \%$ & 17,11 & $5.0-6.0 \%$ & $7.60 \%$ \\
\hline 2006 & $8 \pm 1 \%$ & 4,18 & $8 \pm 1 \%$ & 6,60 & $4.0-5.0 \%$ & $6.20 \%$ \\
\hline 2007 & $6 \pm 1 \%$ & 3,64 & $6 \pm 1 \%$ & 6,59 & $4.0-5.0 \%$ & $2.90 \%$ \\
\hline 2008 & $5 \pm 1 \%$ & 5,67 & $5 \pm 1 \%$ & 11,06 & $4.0 \pm 1 \%$ & $8.30 \%$ \\
\hline 2009 & $4,5 \pm 1 \%$ & 4,88 & $4,5 \pm 1 \%$ & 2,78 & $3.5 \pm 1 \%$ & $4.20 \%$ \\
\hline 2010 & $5 \pm 1 \%$ & 5,03 & $5 \pm 1 \%$ & 6,96 & $4.5 \pm 1 \%$ & $3.80 \%$ \\
\hline 2011 & $5 \pm 1 \%$ & 6,63 & $5 \pm 1 \%$ & 3,79 & $4.0 \pm 1 \%$ & $4.60 \%$ \\
\hline 2012 & $4,5 \pm 1 \%$ & 5,40 & $4,5 \pm 1 \%$ & 4,30 & $4.0 \pm 1 \%$ & $3.20 \%$ \\
\hline 2013 & $4.5 \pm 1 \%$ & 6,20 & $4.5 \pm 1 \%$ & 8,38 & $4.00 \%$ & $3.00 \%$ \\
\hline 2014 & $4.5 \pm 1 \%$ & 6,32 & $4.5 \pm 1 \%$ & 8,36 & $4.00 \%$ & $4.10 \%$ \\
\hline 2015 & $4 \pm 1 \%$ & 9,02 & $4 \pm 1 \%$ & 3,35 & $3.00 \%$ & $1.40 \%$ \\
\hline 2016 & $4 \pm 1 \%$ & 8,73 & $4 \pm 1 \%$ & 3,02 & $3.00 \%$ & $1.80 \%$ \\
\hline $2017 *$ & $4 \pm 1 \%$ & 3,44 & $4 \pm 1 \%$ & 3,61 & $3.00 \%$ & $3.20 \%$ \\
\hline $2018 *$ & $3,5 \pm 1 \%$ & 3,66 & $3,5 \pm 1 \%$ & 3,13 & $3.00 \%$ & $5.20 \%$ \\
\hline
\end{tabular}

Sources: Indonesian Economic and Financial Statistics (SEKI), Central Bank of the Philippines and Branco Central Do Brasil

The level of price stability (inflation) in Indonesia has fluctuated annually from 2010-2018. The increase in world food commodity prices since the end of 2017 which automatically increases the company's cost of production has also contributed to a very large inflation rate. In 2013, the inflation rate reached 8.38 percent due to the increase in fuel prices. The inflation rate for the 2015-2018 period has begun to stabilize and is still within the government's prediction inflation target. The Philippines has also shown an inflation 
rate that has fluctuated in several years. In 2015 and 2016 the government targeted inflation was not achieved, however the Philippines was still able to maintain the inflation rate in the range of $3-4 \%$. In Brazil, between the inflation target and actual

The discrepancy between the actual inflation and the inflation target with various values, there are those that are above the inflation target and also below the inflation target, some data also have a far distance from the target. This also shows that Brazil, the Philippines and Indonesia are still not fully committed to the introduction of price stability so that it has not been effective in influencing the final target of monetary policy, namely price stability (inflation).

Other studies related to price stability (inflation) and exchange rates were also conducted. These studies explain that the exchange rate has an important role in maintaining and stabilizing the amount of inflation so as to achieve macroeconomic and financial system stability. Implementation of the floating exchange rate system in the countries of Indonesia, Brazil and the Philippines, the value of the currency is very volatile because the currency value is determined by the supply and demand mechanism in the foreign exchange market. So that the occurrence of high exchange rate fluctuations will affect (inflation), economic growth, and balance of payments balance. Therefore, the exchange rate has an important role in maintaining and stabilizing the amount of inflation so as to achieve stability in the karo economy and the financial system.

The theory of Purchasing Power Parity (PPP) was introduced by Gustav Cassel in 1918, which explains the relationship between commodity prices in domestic (local) currency and exchange rates. This theory states that the exchange rate will adjust from time to time to reflect the difference in inflation between the two countries, because the purchasing power of consumers to buy dom estic products will be the same as the purchasing power to buy foreign products. the main assumption underlying the PPP theory is that the commodity market is an efficient market in terms of allocation, operations, pricing, and information The relationship between the exchange rate and inflation can be analyzed through the pass throught effect in general, which is to determine the

In addition, when a country imports raw materials, the depreciationofthelocal. currency or appreciation of the foreign currency makes imports expensive and then the production costs for goods increase due to the increase in raw prices. Several studies on the effectiveness of monetary policy instruments in influencing the economy through six transmission lines have been conducted since 2007. Research with inflation, there was a significant deviation from 20022003 where the inflation target was only $3.5 \%$ and $4 \%$, while the actual inflation was very far reaching $8.45 \% 14.71 \%$

effect of changes in exchange rates on changes in prices for imported and exported goods and consumer prices. Focus is given to price changes because it is a fundamental phenomenon. in the formation of product prices that affect changes in consumer prices, and in turn on investment and trade volume. This model is similar to the model developed by Svensson (2000) where the direct effect of the exchange rate on the economy can be through direct effects (direct pass through) or indirect (inderect pass through).

Inflation has become very important when oil prices soar. Since then, controlling the inflation rate has become a top priority for many countries, especially those with small open economies [8]. Indonesia as a country that has an open economy certainly cannot be separated from the influence of the global economy which always influences economic variables. In the study the coefficient of the money supply is positive and statistically significant at the 5 percent significance level. This finding is in accordance with the theory of monetarians who say that an expansionary monetary policy (loose money policy) can increase inflation. This shows that the money supply is an important factor in the inflation process. Besides that, there is a long term relationship between interest rates and inflation as is the finding in Pakistan [9] The availability of imports can affect domestic inflation directly through import prices and indirectly through competition with domestic goods and services.

When domestic demand exceeds the level of domestic output, the mismatch between demand and supply conditions leads to inflation. Responding to this excess demand country can take advantage of import policies . On the other hand, when demand falls below the level of domestic output, inflation will start to erode. In addition, excess output can be handled by exporting to other countries. But this import and export situation also contributes to the origins of inflation. Usually, an increase in imports will cause a depreciation in the exchange rate.

the same topic was conducted in the following years with differences in the number of variables, the number of observations and the research methods used This research will again examine the effectiveness of monetary transmission policy through the exchange rate channel in Indonesia, Philippines and Brazil. 


\section{METHODS}

This research is a de facto expo study that examines the causal relationship between economic concepts based on a country's money supply, exchange, interest rate, import and inflation. The data used were sourced from Bank Indonesia, International Financial Statistic (IFS) and Statistics Indonesia. The analysis model uses VECM in the period 2010Q12018 Q4.
The VECM model is an restricted form of VAR because of the data form in research that is not stationer but cointegrated. VECM is known as a VAR design for non-stationary series which has a cointegration relationship. The VECM model specification restricts the long-term relationship of endogenous variables, but still allows for systematic short-term dynamics of the VECM model, as follows:

1. $\mathrm{INFt}_{-1}=\alpha_{10}+\alpha_{11} \mathrm{ER}_{\mathrm{t}-1}+\alpha_{12} \mathrm{IMP}_{\mathrm{t}-1}+\alpha_{13} \mathrm{SBR}_{\mathrm{t}-1}+\alpha_{14} \mathrm{JUB}_{\mathrm{t}-1}+\mathrm{e}_{\mathrm{t} . \ldots . . .}$ (1)

2. $\mathrm{ERt}_{-1}=\alpha_{20}+\alpha_{21} \mathrm{INF}_{\mathrm{t}-1}+\alpha_{22} \mathrm{SBR}_{\mathrm{t}-1}+\alpha_{23} \mathrm{IMP}_{\mathrm{t}-1}+\alpha_{24} \mathrm{JUB}_{\mathrm{t}-1}+\mathrm{e}_{\mathrm{t} . \ldots . .}$ (2)

3. SBRt $-1=\alpha_{30}+\alpha_{31} \mathrm{INF}_{\mathrm{t}-1}+\alpha_{32} \mathrm{ER}_{\mathrm{t}-1}+\alpha_{33} \mathrm{IMP}_{\mathrm{t}-1}+\alpha_{34} \mathrm{JUB}_{\mathrm{t}-1}+\mathrm{e}_{\mathrm{t} . \ldots . . .}$. (3)

4. $\mathrm{IMPt}_{-1}=\alpha_{40}+\alpha_{41} \mathrm{INF}_{\mathrm{t}-1}+\alpha_{42} \mathrm{SBR}_{\mathrm{t}-1}+\alpha_{43} \mathrm{ER}_{\mathrm{t}-1}+\alpha_{44} \mathrm{JUB}_{\mathrm{t}-1}+\mathrm{e}_{\mathrm{t} \ldots \ldots . .}$. (4)

5. $\mathrm{JUBt}_{-1}=\alpha_{60}+\alpha_{61} \mathrm{INF}_{\mathrm{t}-1}+\alpha_{62} \mathrm{ER}_{\mathrm{t}-1}+\alpha_{63} \mathrm{IMP}_{\mathrm{t}-1}+\alpha_{64} \mathrm{SBR}_{\mathrm{t}-1}+\mathrm{e}_{\mathrm{t}}$.

Where JUB is money supply, IMP is Import, SBR is Real interest rate, INF is inflation, and $\mathrm{ER}$ is

\section{RESULTS AND DISCUSSION}

\subsection{Stationary Test}

Unit root test is a test that aims to determine whether there is stationarity in the data where stationarity is an important thing related to research that uses time series data. Unit root tests emerged and were developed by Dickey-Fuller or commonly known as the Dickey-Fuller (DF) unit root test. And to find out whether there is a stationary unit root test is carried out using the Augmented Dickey-Fuller (ADF)
Exchange Rate, e $e_{\mathrm{t}}$ a residual term , $\alpha_{10} \alpha_{11}+\alpha_{12}+$ $\alpha_{13}+\alpha_{14}$ is a coeficient

Table 2. Stationary Test Results for Each Variable

\begin{tabular}{|c|c|c|c|}
\hline Variable Name & Country & Level & Probability Value \\
\hline \multirow[t]{3}{*}{ 1. Exchange rate } & Brazil & $1^{\text {st }}$ difference & 0.0000 \\
\hline & Philipina & $1^{\text {st }}$ difference & 0.0000 \\
\hline & Indonesia & $1^{\text {st }}$ difference & 0.0001 \\
\hline \multirow[t]{3}{*}{ 2. Inflation } & Brazil & $2^{\text {nd }}$ difference & 0.0000 \\
\hline & Philipina & $1^{\text {st }}$ difference & 0.0190 \\
\hline & Indonesia & $1^{\text {st }}$ difference & 0.0246 \\
\hline \multirow[t]{3}{*}{ 3. Real Interest rate } & Brazil & $1^{\text {st }}$ difference & 0.0017 \\
\hline & Philipina & $1^{\text {st }}$ difference & 0.0025 \\
\hline & Indonesia & $1^{\text {st }}$ difference & 0.0422 \\
\hline \multirow[t]{3}{*}{ 4. Money Supply } & Brazil & $1^{\text {st }}$ difference & 0.0000 \\
\hline & Philipina & $2^{\text {nd }}$ difference & 0.0000 \\
\hline & Indonesia & $2^{\text {nd }}$ difference & 0.0000 \\
\hline \multirow[t]{3}{*}{ 5. Import } & Brazil & $1^{\text {st }}$ difference & 0.0000 \\
\hline & Philipina & $1^{\text {st }}$ difference & 0.0000 \\
\hline & Indonesia & $2^{\text {nd }}$ difference & 0.0000 \\
\hline
\end{tabular}


The variable is stationary at a certain level, namely the 1 st difference, or 2 nd difference. From this table it can be seen that the exchange rate variable (Brazil, Philippines and Indonesia) has a small probability value of $\alpha=0.05$ on the 1 st difference. variable exchange rate price stability (inflation) Brazil is stationary in the 2nd difference, (Indonesia, Philipian) is stationary at the 1st difference. Therefore these variables are said to be stationary at the 1 st difference.

\subsection{Lag Optimal}

For optimal log testing, it can be seen from the interval candidates selected are the interval length according to the Akaike Information Criteria (AIC) criteria, the Schwaz Information Criterion (SIC), and

\subsection{Cointegration Test}

In this step you can know what model to use. Is the VAR model at the level of differentiation (if there is no cointegration) or VECM model (if there is cointegration). In the cointegration method there are methods that can be used, among others: the EngleGranger cointegration method and the Johanes cointegration method. In this study using Johanes cointegration test.

Cointegration testing shows that the trace test indicated that there were 4 cointegration. The
Variable real interest rates (Brazil, Philippines and Indonesia). The variable in the money supply (Brazil, Indonesia) is stationary in the $1 \mathrm{st}$ difference (Philippines) stationary in the 2nd difference. the import variable has a small probability value of $\alpha=$ 0.05 at the 1 st difference in the country (Brazil and the Philippines) while the Indonesian state is stationary in the 2nd difference.

the Hannan Quinn Criteria (HQC). Can be seen with the most $*$ sign.the output above the most $*$ sign in lag 1 and 4 .

relationship of mutual influence can be seen from the cointegration that occurs between the variables themselves. Based on the cointegration test there is a cointegration equation at a significant level of 5 percent. Then it can be concluded that the data are cointegrated. This shows that there is a long-term relationship between the variables of the level of inflation, and money supply, exchange rate, Import and real interest rate Co-integration of a variable shows the right signal to use VECM.

Table 3. VECM Brazil

\begin{tabular}{|l|c|c|c|}
\hline \multicolumn{1}{|c|}{ Variable } & Coefisien & t-statistik & Decision \\
\hline Long run & & & \\
\hline Inflation & & & Significan \\
\hline Money Supply & $1.2 \mathrm{E}-05$ & -3.77792 & Significan \\
\hline Real Interst Rate & 0.33000 & -2.69975 & Significan \\
\hline Exchange rate & 1.83832 & -3.94787 & Not Significan \\
\hline Import & 0.00012 & -5.84306 & Significan \\
\hline Short run & & & Not Significan \\
\hline CointEq1 & -0.08658 & -1.73482 & Not Significan \\
\hline Inflation & -0.24900 & -3.70048 & Not Significan \\
\hline Money Supply & $4.1 \mathrm{E}-06$ & 0.35546 & Not Significan \\
\hline Real Interst Rate & 0.35172 & -0.33856 & 0.90504 \\
\hline Exchange rate & -0.90504 & 0.81247 & \\
\hline Import & $4.7 \mathrm{E}-05$ & & \\
\hline
\end{tabular}

Based on table 2 with a t-statistic value of Money Supply -3.77792, Riil Interest rate --2.69975, exchange rate -3.94787 and Import -5.84306 is greater than t-table - 1.96 has a significant effect on the money supply in the long run, where as in the short term the money supply is influenced by the inflation with a t-statistic value of -3.70048 more large than t-table - 1.96 .
Based on table 3 the money supply with a tstatistic value of 3.71628 is greater than t-table 1.96 and import with a t-statistic value of 7.13338 is greater than t-table - 1.96 has a significant effect on e-money in the long run, whereas in the short run e-money is influenced by the exchange rate with a coefisient value of 0.00016 
Table 4. VECM Indonesia

\begin{tabular}{|l|c|c|c|}
\hline \multicolumn{1}{|c|}{ Variable } & Coefisien & t-statistik & Decision \\
\hline Long run & & & \\
\hline Inflation & & & Significan \\
\hline Money Supply & $9.8 \mathrm{E}-09$ & 3.71628 & Not Significan \\
\hline Real Interst Rate & 0.42488 & 0.45683 & Significan \\
\hline Exchange rate & 0.00094 & 0.52196 & Significan \\
\hline Import & 0.00027 & 7.13338 & Not Significan \\
\hline Short run & & & Not Significan \\
\hline CointEq1 & 0.03933 & -0.67148 & Not Significan \\
\hline Inflation & 0.23292 & -0.17349 & Not Significan \\
\hline Money Supply & $1.7 \mathrm{E}-09$ & 0.31469 & Not Significant \\
\hline Real Interest Rate & 0.13591 & -0.13591 & 0.61526 \\
\hline Import & $6.0 \mathrm{E}-05$ & 0.37802 & \\
\hline Exchange rate & 0.00016 & &
\end{tabular}

Table 5. VECM Philippines

\begin{tabular}{|l|c|c|c|}
\hline \multicolumn{1}{|c|}{ Variable } & Coefisien & t-statistik & Decision \\
\hline Long run & & & \\
\hline Inflation & & & Significan \\
\hline Money Supply & $2.0 \mathrm{E}-05$ & -7.55709 & Not Significan \\
\hline Real Interst Rate & 3.57010 & -1.05119 & Significan \\
\hline Exchange rate & 4.21265 & -0.40940 & Not Significan \\
\hline Import & 0.00546 & -2.62504 & Not Significan \\
\hline Short run & & & Not Significan \\
\hline CointEq1 & 0.00651 & -1.56213 & Not Significan \\
\hline Inflation & 0.4579 & -1.61034 & Not Significan \\
\hline Money Supply & $8.2 \mathrm{E}-07$ & -1.87488 & -0.01016 \\
\hline Real Interest Rate & 0.33351 & -0.63843 & signican \\
\hline Import & 0.00012 & & money \\
\hline
\end{tabular}

Based on table 4, the money supply with a tstatistic value of -7.55709 is greater than t-table -1.96 and import with a t-statistic value of 2.62504 is greater than t-table 1.96 which has a significant effect on interest rates in the long run, whereas in the short term interest is influenced by money supply with a tstatistic value of 2.62504 greater than t-table 1.96 .

\subsection{Variable Response Test (Impulse Response Function)}

The Impulse Response Function tracks the effect of changing one standard deviation of one innovation of a variable on the present and future value of another variable in the VECM equation system. This method can be used to determine the response of an endogenous variable to a particular variable. Because actually the shock of a variable to one does not only affect that one variable, but also is transmitted to all other endogens through dynamic structures or lag structures in VECM. 

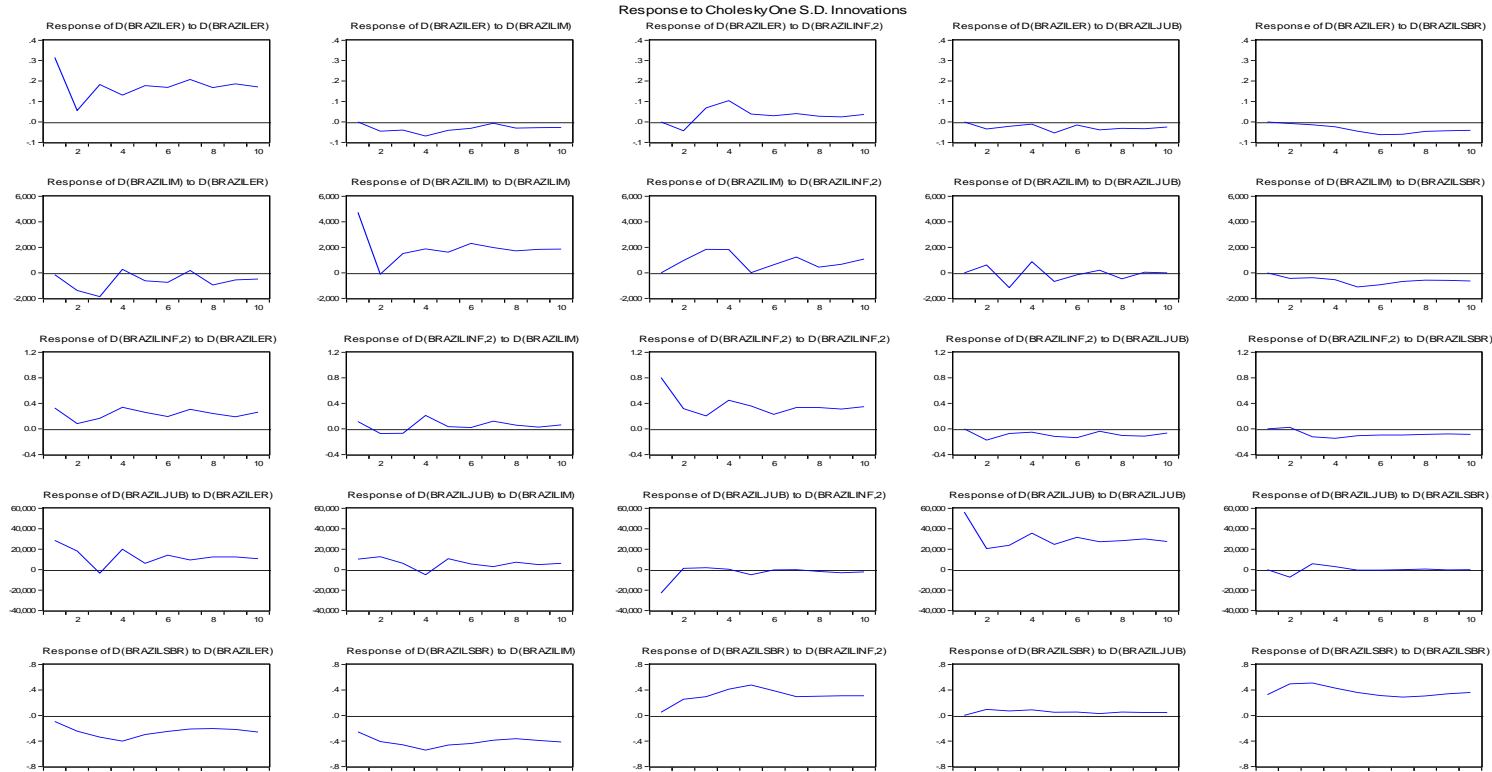

Figure 1. Impulse Response Function between Inflation, Exchange rate, Import, Money Supply and interest rate Brazil.

Based on the results of the IRF which explains the inflation response to shocks from several variables in the exchange rate channel in Brazil, which include exchange rates, imports, real interest rates, and the money supply and inflation itself. These results indicate that for shocks caused by exchange rate behavior, inflation has a positive response with the lowest value of 0.076123 in the 4th period. Meanwhile, for other variables in the exchange rate

channel, namely imports as a result of the shock of these variables, it was responded negatively by inflation with the highest value in the fourth period, for the SBR shock was responded by positive negative inflation of -0.2555574 in the fourth period. While the shocks due to JUB's behavior responded positively and negatively with the highest response of -0.264543 in period 2 and positive in period 6 of 0.054924
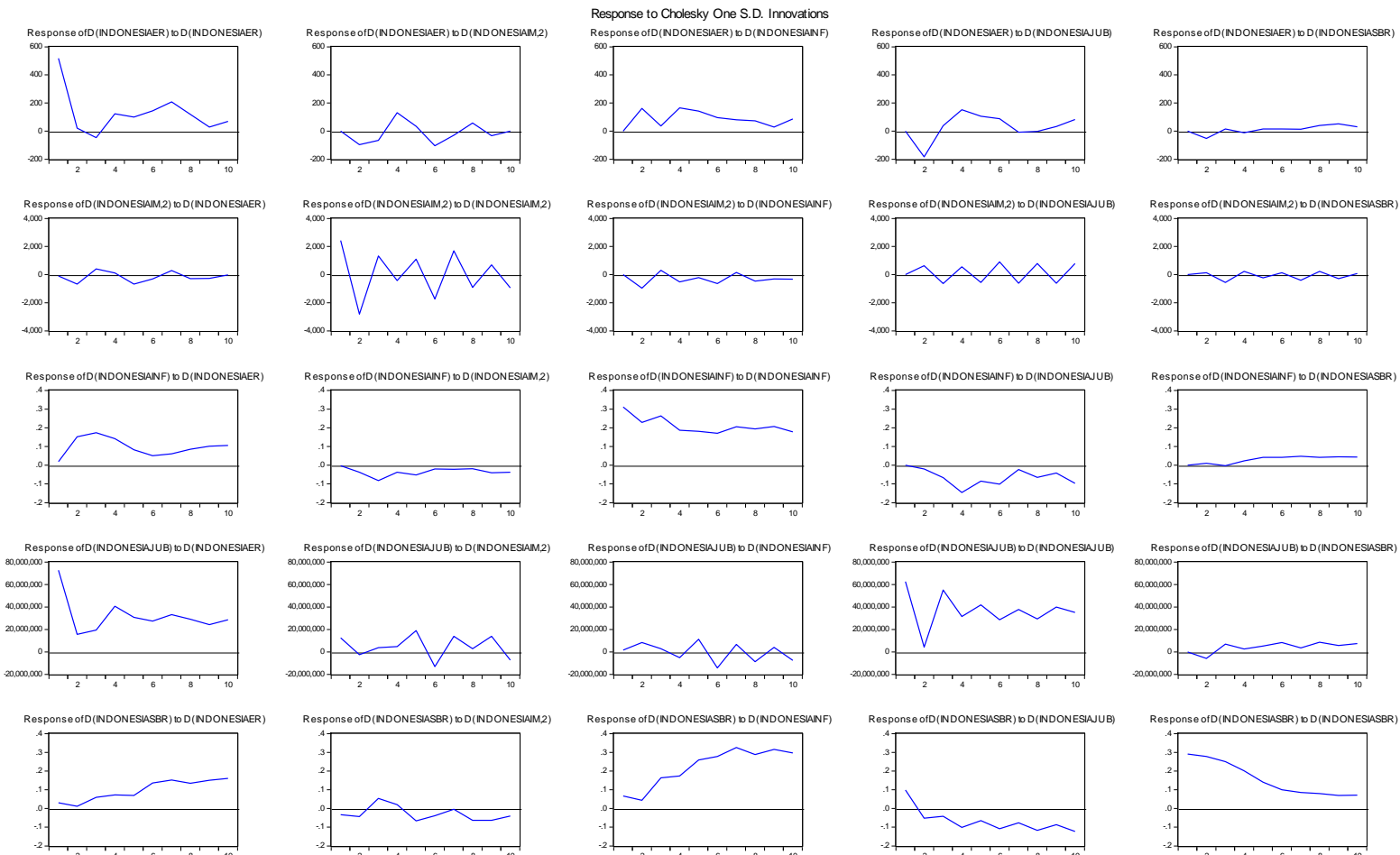

Figure 2. Impulse Response Function between Inflation, Exchange rate, Import, Money Supply and interest rate Indonesia. 
Based on the results of the IRF which explains the inflation response to shocks from several variables in the exchange rate channel in Brazil, which include exchange rates, imports, real interest rates, and the money supply and inflation itself. These results indicate that for shocks caused by exchange rate behavior, inflation has a positive response with the lowest value of 0.076123 in the 4th period. Meanwhile, for other variables in the exchange rate
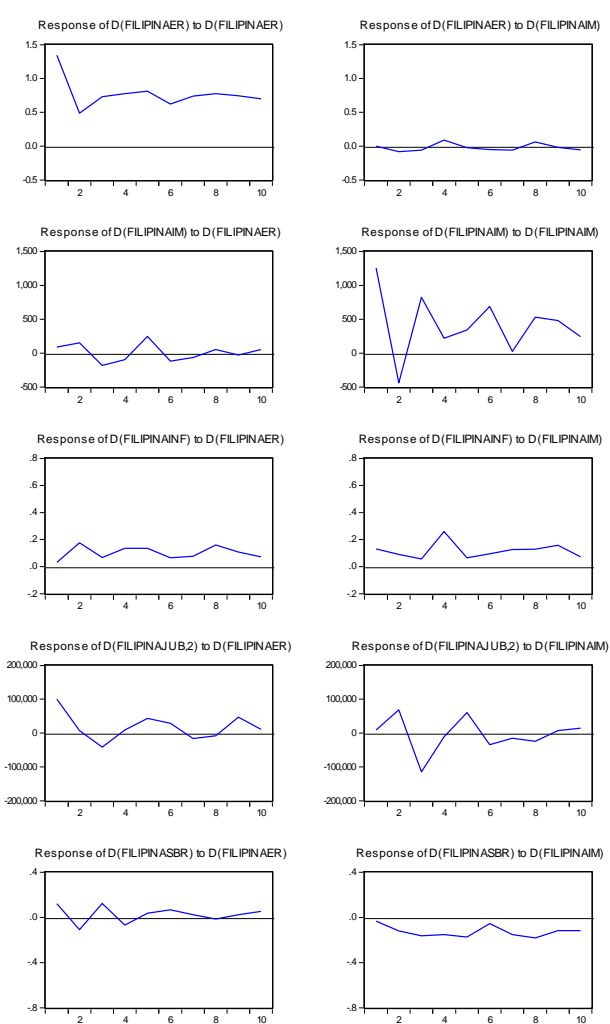

Figure 3. Impulse Resp interest rate Philippines. channel, namely imports as a result of the shock of these variables, it was responded negatively by inflation with the highest value in the fourth period, for the SBR shock was responded by positive negative inflation of -0.2555574 in the fourth period. While the shocks due to JUB's behavior responded positively and negatively with the highest response of -0.264543 in period 2 and positive in period 6 of 0.054924 .
Response to Cholesky One S.D. Innovation

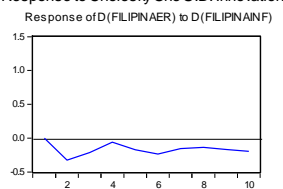

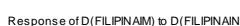
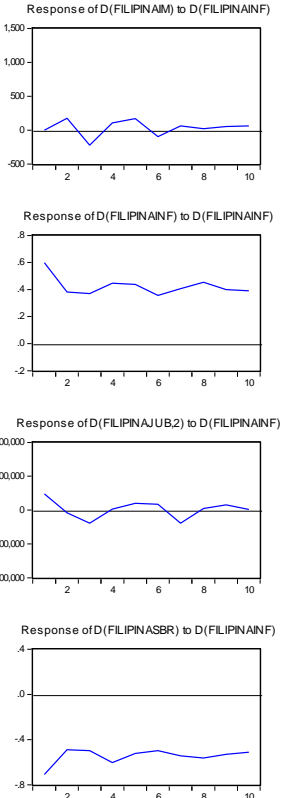
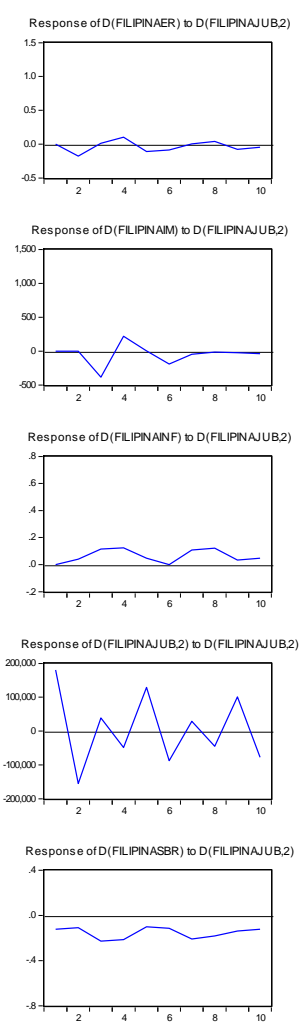

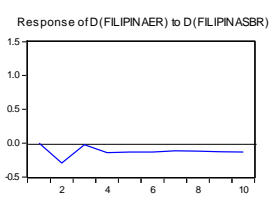

Response ofD(FILIPNAM) to D(FIIPNASS
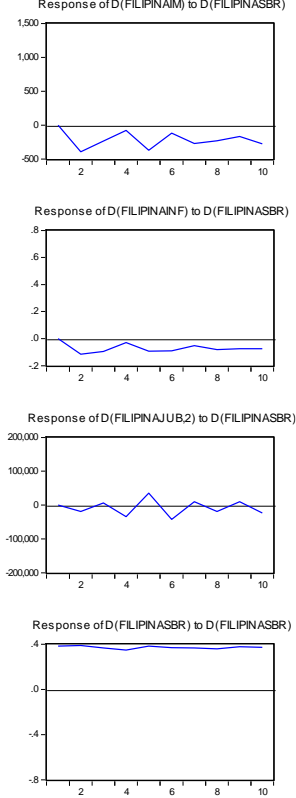

Supply and 
Table 5. Variance Decomposition Inflasi Philippines

\begin{tabular}{|c|c|c|c|c|c|c|}
\hline Period & S.E. & $\begin{array}{c}\text { (FILIPINAAI } \\
\text { NF) }\end{array}$ & $\begin{array}{c}\text { (FILIPINABJ } \\
\text { UB,2) }\end{array}$ & $\begin{array}{c}\text { (FILIPINADI } \\
\text { M) }\end{array}$ & $\begin{array}{c}\text { D(FILIPINACS } \\
\text { BR) }\end{array}$ & $\begin{array}{c}\text { (FILIPINAEE } \\
\text { R) }\end{array}$ \\
\hline 1 & 0.618688 & 100.0000 & 0.000000 & 0.000000 & 0.000000 & 0.000000 \\
\hline 2 & 0.774010 & 91.74818 & 1.344660 & 0.490095 & 0.248062 & 6.169006 \\
\hline 3 & 0.878016 & 89.61558 & 3.063162 & 0.480265 & 1.249395 & 5.591594 \\
\hline 4 & 1.050356 & 87.08295 & 3.396953 & 3.791908 & 0.913646 & 4.814539 \\
\hline 5 & 1.154501 & 86.72930 & 3.328133 & 3.168592 & 1.212690 & 5.561287 \\
\hline 6 & 1.222089 & 86.98575 & 2.981386 & 3.031117 & 1.423487 & 5.578258 \\
\hline 7 & 1.308263 & 87.29785 & 3.288435 & 3.027292 & 1.360615 & 5.025805 \\
\hline 8 & 1.415582 & 86.46384 & 3.984534 & 2.844416 & 1.311030 & 5.396183 \\
\hline 9 & 1.488665 & 86.51620 & 3.671275 & 2.900844 & 1.357755 & 5.553931 \\
\hline 10 & 1.547323 & 86.89678 & 3.567984 & 2.705313 & 1.448184 & 5.381740 \\
\hline
\end{tabular}

Table 6. Variance Decomposition Inflation Brazil

\begin{tabular}{|c|c|c|c|c|c|c|}
\hline Period & S.E. & $(\mathrm{INF}, 2)$ & $(\mathrm{JUB})$ & (SBR) & (DIM) & (EER) \\
\hline 1 & 0.835139 & 100.0000 & 0.000000 & 0.000000 & 0.000000 & 0.000000 \\
\hline 2 & 0.967410 & 86.59016 & 7.477787 & 1.092405 & 3.981624 & 0.858024 \\
\hline 3 & 1.046855 & 81.19868 & 6.729819 & 1.539035 & 8.959688 & 1.572780 \\
\hline 4 & 1.232009 & 81.73198 & 4.861062 & 5.414533 & 6.475090 & 1.517337 \\
\hline 5 & 1.338160 & 80.07236 & 4.164603 & 5.252118 & 6.861565 & 3.649352 \\
\hline 6 & 1.402661 & 77.87899 & 3.943725 & 5.705669 & 7.958004 & 4.513612 \\
\hline 7 & 1.509394 & 78.72049 & 3.414406 & 6.331599 & 7.074484 & 4.459019 \\
\hline 8 & 1.598469 & 79.00832 & 3.087084 & 5.983775 & 7.212590 & 4.708235 \\
\hline 9 & 1.660742 & 78.14283 & 2.938624 & 6.111546 & 7.556366 & 5.250634 \\
\hline 10 & 1.737452 & 78.28220 & 2.690898 & 6.452763 & 7.287450 & 5.286692 \\
\hline
\end{tabular}

Based on the VD test results, it is found that the final goal of monetary policy (inflation) affects all variables in the exchange rate channel in Brazil. The results show that the strong influence shown by imports of $7.28 \%$ in the 10th period JUB of $2.69 \%$ affects inflation in period 2. The SBR of $6.45 \%$ affects inflation in the 10th period and the exchange rate of $5.28 \%$ influences inflation in period 10 . period 10 The long-term equilibrium result through VECM also explains between the exchange rate and inflation which implies the need to strengthen the exchange rate to reduce the rate of inflation through the concept of international trade. This is in accordance with the purchasing power parity theory in which the contribution of forming domestic inflation is a result of the existing exchange rate. This result is also in accordance with research conducted by [10]

Table 7. Variance Decomposition Inflation Indonesia

\begin{tabular}{|c|c|c|c|c|c|c|}
\hline Period & S.E. & $($ INF) & $(J U B)$ & $($ SBR $)$ & $($ ER $)$ & $($ IM) \\
\hline 1 & 0.358718 & 100.0000 & 0.000000 & 0.000000 & 0.000000 & 0.000000 \\
\hline 2 & 0.479244 & 97.00149 & 0.733698 & 0.050103 & 1.660106 & 0.554604 \\
\hline 3 & 0.617887 & 93.13974 & 2.074669 & 0.260437 & 2.383338 & 2.141819 \\
\hline 4 & 0.715861 & 92.97153 & 1.751955 & 0.438145 & 3.006726 & 1.831641 \\
\hline 5 & 0.798958 & 92.73053 & 2.344715 & 0.368954 & 2.931690 & 1.624116 \\
\hline 6 & 0.873510 & 92.64820 & 2.185281 & 0.419607 & 3.152227 & 1.594683 \\
\hline 7 & 0.948905 & 92.60353 & 2.216615 & 0.401169 & 3.064770 & 1.713917 \\
\hline 8 & 1.012788 & 92.42858 & 2.236518 & 0.422241 & 3.234470 & 1.678194 \\
\hline 9 & 1.075477 & 92.45387 & 2.309578 & 0.418130 & 3.242151 & 1.576272 \\
\hline 10 & 1.132937 & 92.42642 & 2.253700 & 0.412042 & 3.258194 & 1.649649 \\
\hline
\end{tabular}


Based on the VD test results, it is found that the final goal of monetary policy (inflation) affects all variables in the exchange rate channel in Indonesia. The results show that the strong influence is shown by the exchange rate of $3.25 \%$ in the 10 th period. Furthermore, the JUB variable of $2.25 \%$ affects

\section{CONCLUSIONS}

This study examines the effectiveness of monetary policy transmission in Brazil, Philippines and Indonesia can be seen from two indicators, the first is through the Impulse Response Factor (IRF) test and the Variance Decomposition (VD) test. Based on these indicators, the results show that for Brazil the exchange rate channel has not been effective in achieving the final target of monetary policy, namely price stability (inflation) because the magnitude of the influence of the exchange rate variable on inflation is only $5.28 \%$. The influence of the SBR is greater than the exchange rate of $6.45 \%$, the influence of imports on inflation is $7.28 \%$ and JUB has an influence on inflation of $3.56 \%$. In the Philippines, based on this indicator, the results show that for the Philippines, the

\section{REFERENCES}

[1] K. Srithilat and G. Sun, "The Impact of Monetary Policy on Economic Development : Evidence from Lao PDR," Glob. J. HumanSocial Sci. E Econ., vol. 17, no. 2, pp. 9-16, 2017.

[2] H. Le Viet and W. D. Pfau, "Var analysis of the monetary transmission mechanism in Vietnam," Appl. Econom. Int. Dev., vol. 9, no. 1, pp. 165-179, 2009.

[3] M. K. Fuddin, "Effectiveness of monetary policy transmission in Indonesia," Econ. J. Emerg. Mark., vol. 6, no. 2, pp. 119-130, 2014, doi: 10.20885/ejem.vol6.iss2.art5.

[4] S. G. Cecchetti, "Policy Rules and Targets: Framing the Central Banker's Problem," pp. 1-14, 1998.

[5] L. CARBONARI, "Transmission Mechanism of Monetary Policy," Bankpedia Rev., vol. 4, no. 1, pp. 25-29, 2014, doi: 10.14612/carbonari_1_2014.

[6] D. Asteriou, K. Masatci, and K. Pilbeam, "Exchange rate volatility and international trade: International evidence from the MINT countries," Econ. Model., vol. 58, no.

November, pp. 133-140, 2016, doi: 10.1016/j.econmod.2016.05.006. inflation in the 10th period. The results of this study are in accordance with research conducted by (Poon, 2010) where the effective channel in Malaysia is the exchange rate channel that affects Malaysian international trade and impacts the real sector. including

Inflation

exchange rate channel has been effective in achieving the final target of monetary policy, namely price stability (inflation) because the magnitude of the influence of the exchange rate variable on inflation is only $5.38 \%$. The influence of the SBR on inflation is $1.4 \%$, the influence of imports on inflation is $2.7 \%$ and JUB has an influence on inflation of $3.56 \%$. Based on these indicators, the results show that for Indonesia, the exchange rate channel is effective in achieving the final target of monetary policy, namely price stability (inflation) because the influence of the exchange rate variable on inflation is $3.25 \%$. The influence of the SBR is $0.41 \%$, the influence of imports on inflation is $1.64 \%$ and JUB has an influence on inflation of $2.25 \%$.

[7] S. Anwar and L. P. Nguyen, "Channels of monetary policy transmission in Vietnam," $J$. Policy Model., vol. 40, no. 4, pp. 709-729, 2018, doi: 10.1016/j.jpolmod.2018.02.004.

[8] D. Dacosta, “by,” Determ. Inflat. Sel. Caribb. Ctries. by Kevin Greenidge1 Dianna DaCosta Abstr., no. 246, pp. 371-397, 2001.

[9] L. C. Khumalo, E. Mutambara, and A. Assensoh-Kodua, "Relationship between inflation and interest rates in Swaziland revisited," Banks Bank Syst., vol. 12, no. 4, pp. 218-226, 2017, doi: 10.21511/bbs.12(41).2017.10.

[10] R. Islam, A. B. Abdul Ghani, E. Mahyudin, and N. Manickam, "Determinants of Factors that Affecting Inflation in Malaysia," Int. J. Econ. Financ. Issues, vol. 7, no. 2, pp. 355364, 2017. 